\title{
Effect of Different Treatment Regimen and Types of Endodontic Sealers on Pain and Periapical Radiographic Changes
}

\author{
Mona Yehia* ${ }^{1 *}$, Magdy Mohamed $^{2}$ (D) Lamia Ibrahim $^{3} \mathbb{D}$, Dalia Moukarab ${ }^{1}$ (D) \\ ${ }^{1}$ Department of Endodontics, Faculty of Dentistry, Minia University, Minya, Egypt; ${ }^{2}$ Department of Endodontics, Faculty of \\ Dentistry, Beni-Suef University, Beni Suef, Egypt; ${ }^{3}$ Department of Endodontics, Faculty of Dentistry, Fayoum University, \\ Faiyum, Egypt
}

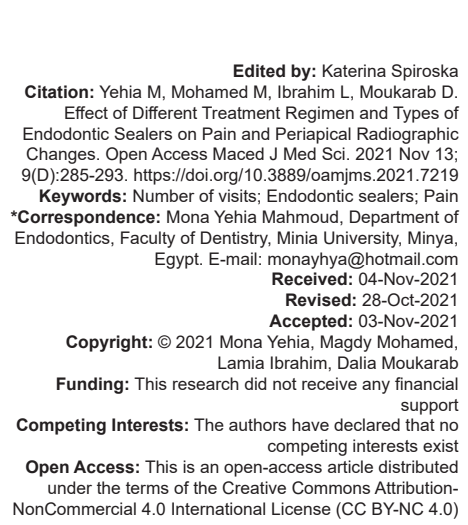

\section{Abstract}

INTRODUCTION: The study aims as a pilot study to evaluate the effect of different treatment regimen and different types of endodontic sealers on pain and periapical radiographic changes was studied.

MATERIALS AND METHODS: Forty patients in need of an endodontic root canal treatment on anterior teeth were selected and divided into two groups (20 patients each), according to the endodontic treatment protocol (single or multiple visits). Then, each group was subdivided into two subgroups according to sealer used 10 each (AH Plus Jet resin sealer Total Fill Bioceramic Sealer). To record pain intensity of the patients at different intervals: 1, 2, 3, 7 days, a visual analog scale was used. Furthermore, patients were recalled after 1, 3, 6, 9 months to evaluate periapical radiographic changes.

RESULTS: Showed that as regard pain assessment both tested endodontic sealers, as well as single or multiple visits have no statistically significant difference between pain values of patients during all the observation period from immediately post-operative, after $4,12,24,48,72 \mathrm{~h}$ as well as after 7 days $(p>0.05)$. As regard lamina dura thickness, results showed that with both tested endodontic sealers as well as single or multiple visits, there was no statistically significant difference between lamina dura thickness of patients after 1 month, 3, 6 as well as after 9 months.

CONCLUSIONS: Neither number of visits of endodontic treatment nor type of sealer used for obturation affects post-operative pain and thickness of lamina dura.

\section{Introduction}

In previous studies, post-operative pain reports in endodontics range from $3 \%$ to $58 \%$ [1]. Pain can be provoked by mechanical, chemical, or microbiological injuries to periodontal tissues [2]. The presence of post-operative pain has been shown to be associated with a number of treatment parameter, the number of visits [3], [4], the choice of root canal sealer [5], the choice of instrumentation [6], [7], [8], [9], [10], including working length (WL) estimation [11], [12], [13].

Several researchers pointed out the number of visits as an important factor in post-operative pain. There is a controversy in the dental literature concerning the competition of endodontic therapy in one or multiple appointments [14]. There are several factors concerning the choice of the type of treatment: tooth conditions (vital or nonvital tooth, symptomatic or asymptomatic, presence or absence of swelling), operator ability and clinical experience, medical history and attitude, anatomic and biologic considerations, adequate treatment time, patient's time constraints [15].

Several types of endodontic sealers are available in the market, and they may play a significant role in post-operative endodontic pain [16]. This may be due to the fact that sealers placed in the root canals interfere with periodontal tissues through the apical foramina, lateral canals, or leaching and can potentially affect the healing process in the periodontium. Hence, local inflammation may occur due to root canal obturation materials which may cause post-operative pain. The intensity of inflammatory reactions depends on a number of different factors including the composition of the sealer [17].

It was reported that bioceramic materials play an important role in improving the outcome of endodontic treatment, because it releases biologically active substances [18], [19], [20], and it promotes the differentiation of odontoblasts [21]. Concerning cytotoxicity, bioceramic materials have been shown to be less cytotoxic than resin-based AH Plus in vitro [22]. On the other hand, AH Plus exhibited higher radiopacity [18] and stronger bonding capacity [23] compared with bioceramic sealers. In the dental literature, the clinical behavior of bioceramic sealers data is rare and of great interest.

As regard the null hypothesis, the researchers predict that there is no difference in pain reaction and lamina dura thickness for both number of visits as well as types of tested sealers. 


\section{Materials and Methods}

\section{Materials}

Two types of endodontics sealers were used, representing two categories of endodontic sealers (Table 1):

Table 1: The materials used in this study

\begin{tabular}{|c|c|c|}
\hline Endodontic sealer & Composition & Batch number \\
\hline $\begin{array}{l}\text { AH Plus Jet (Densply, } \\
\text { Detrey, Konstanz, } \\
\text { Germany) }\end{array}$ & $\begin{array}{l}\text { Paste A: Bispheol-A epoxy resin, Bisphenol-F } \\
\text { epoxy resin, calcium tugstate, zirconium oxide, } \\
\text { silica and iron pigments. } \\
\text { Paste B: Dibenzyl diamine, aminoadamantane, } \\
\text { tricyclodecane-diamine, calcium tungstate and } \\
\text { zirconium oxide }\end{array}$ & 1512000341 \\
\hline $\begin{array}{l}\text { Total Fill (Brasseler, } \\
\text { USA, Savannah, GA) }\end{array}$ & $\begin{array}{l}\text { Zirconium oxide, calcium silicates, calcium } \\
\text { phosphate, calcium hydroxide, filler, thickening } \\
\text { agents }\end{array}$ & $15003 \mathrm{SP}$ \\
\hline
\end{tabular}

\section{Methods}

\section{Study design}

This study was a randomized clinical comparing two endodontics sealers (AH Plus Jet resin sealer, Total Fill Bioceramic sealer). This research project was approved by the local research Ethics Committee (article number 234) and was performed in compliance with the ethical standards laid down in the 1946 declaration of Helsinki. Sample size calculation was based on a previous study. It considered an error of alpha $=0.05$ and a power of 0.994 and indicated a required sample size of 10 patients in each group, thus a total of 40 patients were included in this study.

\section{Participant selection}

Patients referred for endodontic treatment at the Faculty of Dentistry, Minia University between January 2019 and October 2019 were invited to participate in this study. They were given complete information on the purpose and methods of the study, and those who agreed to participate signed an informed consent form. Inclusion criteria: Patient age in the range of (18-40) years old referred to undergo endodontic treatment for upper anterior teeth and diagnosed as acute pulpitis without apical rarefaction, with slight pain on percussion and slight periodontal ligament space widening.

\section{Exclusion criteria}

Patients using pre-operative drugs that can affect pain perception as anti-inflammatory, analgesics or antibiotics in the past $24 \mathrm{~h}$ also, allergic s or pregnant patients. Finally, patients diagnosed as having teeth with periapical radiolucency, necrotic pulp, swelling, or sinus tract. Teeth requiring retreatment. Teeth with grade II or III mobility.

\section{Randomization and blinding}

Stratified randomization was performed according to different tested groups, using a table of computer-generated random number. Allocation was concealed using envelopes were opened by an assistant not involved in the research, but only when the endodontic sealer was going to be inserted into the root canal. The patients were randomized for the endodontic sealer used. Table 1 states the endodontic sealers used and their compositions. The operator knew which sealer would be used only right before filling the root canal. The patients were blinded to the sealer.

\section{Clinical intervention}

Teeth were treated by one experienced endodontist. Local anesthesia and dental dam isolation as a routine steps were performed. Then, access was done following by the determination of the WL using an electronic apex locator (Root ZX II; J Morita, Irvine, CA). A radiograph was taken to confirm the $\mathrm{WL}$, when a reliable electronic apex locator reading could not be achieved.

The canals were prepared using Revo S rotary instrumentation (Revo S rotary files Micro-Mega, France apical file). Between each file irrigation was performed with $2 \mathrm{ml}$ of $2.5 \%$ sodium hypochlorite using Endo-Eze irrigation tip (Ultradent Products Inc., Jordan) with (27) gauge needle.

The patients were divided into two groups according to the number of treatment visits. Group I, single visit (20 patients) and Group II, multiple visits (20 patients). Then, the patients were randomly subdivided into two subgroups (10 patients each) according to the type of endodontic sealer used. $\mathrm{AH}$ Plus Jet resin sealer (DentSply, Kostanz, Germany) was used for patients in subgroup $A$ and Total Fill Bioceramic sealer (Brasseler, USA, Savannah, GA) was used for patients in subgroup $B$.

For patients in Group I, after mechanical preparation, root canals were dried using absorbent paper points size 40 (Meta Biomed Co. Ltd, Korea) and root canals were obturated with master cone size 40 ISO standardized gutta percha cone (Meta Biomed Co. LTD). The sealer was used according to manufacturer's instructions. A pre-fitted ISO size 40 gutta percha master cone was inserted to full WL and accessory gutta percha size 25 was used. While for patients in subgroup B, Total Fill bioceramic sealer (Brasseler, USA, Savannah, GA) was used. The sealer was used according to the manufacturer's instructions. A prefitted Total Fill master single cone size 40, 0.04 taper was inserted to full WL.

Access cavity was sealed using Cavit temporary filling (3M ESPE, USA) over a dry cotton pellet. All steps were recorded by operator on a work chart and checked radiographically. The patients were referred to a specialist for a final restoration. For 
Table 2: Comparison between pain VAS scores after single or multiple visits

\begin{tabular}{|c|c|c|c|c|c|c|c|}
\hline \multirow[t]{2}{*}{ Sealer } & \multirow[t]{2}{*}{ Time } & \multicolumn{2}{|c|}{ Single visit $(n=10)$} & \multicolumn{2}{|c|}{ Multiple visits $(n=10)$} & \multirow[t]{2}{*}{$\mathrm{p}$-value } & \multirow[t]{2}{*}{ Effect size (d) } \\
\hline & & Median & Range & Median & Range & & \\
\hline \multirow[t]{8}{*}{ AH Plus } & Pre-operative & 6 & $5-7$ & 5 & $3-7$ & 0.159 & 0.639 \\
\hline & Immediate post-operative & 5 & $0-5$ & 3.5 & $0-6$ & 0.844 & 0.085 \\
\hline & $4 \mathrm{~h}$ & 4.5 & $0-5$ & 4 & $0-6$ & 0.536 & 0.273 \\
\hline & $12 \mathrm{~h}$ & 4 & $3-4$ & 3.5 & $0-5$ & 0.812 & 0.102 \\
\hline & $24 \mathrm{~h}$ & 3 & $2-4$ & 2 & $0-4$ & 0.337 & 0.414 \\
\hline & $48 \mathrm{~h}$ & 3 & $0-3$ & 0.5 & $0-3$ & 0.218 & 0.524 \\
\hline & $72 \mathrm{~h}$ & 0 & $0-0$ & 0 & $0-2$ & 0.067 & 0.524 \\
\hline & 7 Days & 0 & $0-0$ & 0 & $0-0$ & 1 & 0 \\
\hline \multirow[t]{8}{*}{ Total Fill } & Pre-operative & 5 & $4-6$ & 6 & $5-7$ & 0.074 & 0.801 \\
\hline & Immediate post-operative & 3 & $0-4$ & 4 & $3-6$ & 0.615 & 0.204 \\
\hline & $4 \mathrm{~h}$ & 3 & $2-4$ & 4 & $3-4$ & 0.058 & 0.844 \\
\hline & $12 \mathrm{~h}$ & 4 & $3-4$ & 3 & $2-3$ & 0.243 & 0.506 \\
\hline & $24 \mathrm{~h}$ & 4 & $2-4$ & 1 & $0-2$ & 0.071 & 0.801 \\
\hline & $48 \mathrm{~h}$ & 2 & $1-3$ & 0 & $0-1$ & 0.262 & 0.487 \\
\hline & $72 \mathrm{~h}$ & 0 & $0-0$ & 0 & $0-0$ & 1 & 0 \\
\hline & 7 Days & 0 & $0-0$ & 0 & $0-0$ & 1 & 0 \\
\hline
\end{tabular}

patients in group II (multiple visits), after mechanical preparation, root canals were dried using paper points and filled with injectable calcium hydroxide intracanal medication (Meta Biomed Co. Ltd, Korea) and access cavities were sealed with Cavit temporary filling. Patients were recalled after 7 days for completion of treatment; a rubber dam was placed and temporary filling was removed. Calcium hydroxide was removed with manual filling and normal saline and the root canals were dried using paper points and then obturated using tested sealers as mentioned previously in Group I.

\section{Post-operative pain evaluation}

Pain intensity record was established using a visual analog scale (VAS) at 24, 48, $72 \mathrm{~h}$. The VAS consisted of a $10-\mathrm{mm}$-long line divided into 10 equal intervals from 0 (no pain) to10 (very severe pain). Each patient was instructed to mark his or her perceived post-operative pain level on the line. The distance between "no pain" and the mark defined the subject's pain [24].

\section{Post-operative radiographic evaluation}

Patients were recalled after 1, 3, 6, 9 months to evaluate periapical radiographic changes to assess lamina dura and osseous changes. The periapical conditions were classified as following: a. Normal denoting normal appearance of the surrounding osseous structure or

b. Apical periodontitis denoting apical radiolucency observed [25].

\section{Statistically analysis}

Numerical data were explored for normality by checking the distribution of data and using tests of normality (Kolmogorov-Smirnov and Shapiro-Wilk tests). All data showed normal (parametric) distribution except for pain VAS scores which showed non-normal (non-parametric) distribution. Parametric data were presented as mean and standard deviation (SD) values while non-parametric data were presented as median and range values. For parametric data, oneway analysis of variance (ANOVA) test was used to compare between mean age values in the four groups. Repeated measures ANOVA test was used to compare between the two sealers, single and multiple visits as well as to study the changes within each group. Bonferroni's post-hoc test was used for pair-wise comparisons when ANOVA test is significant. For non-parametric data, Mann-Whitney $U$ test was used to compare between the two sealers as well as single and multiple visits. Friedman's test was used to study the changes within each group. Dunn's test was used for pair-wise comparisons when Friedman's test is significant. Qualitative data were presented as frequencies and percentages. Fisher's exact test

Table 3: Comparison between pain VAS scores after single or multiple visits

\begin{tabular}{|c|c|c|c|c|c|c|c|}
\hline \multirow[t]{2}{*}{ Visit } & \multirow{2}{*}{ Time } & \multicolumn{2}{|c|}{ AH Plus $(n=10)$} & \multicolumn{2}{|c|}{ Total Fill $(n=10)$} & \multirow[t]{2}{*}{$p$-value } & \multirow[t]{2}{*}{ Effect size (d) } \\
\hline & & Median & Range & Median & Range & & \\
\hline \multirow[t]{8}{*}{ Single visit } & Pre-operative & 6 & $5-7$ & 5 & $4-6$ & 0.052 & 0.979 \\
\hline & Immediate post-operative & 5 & $0-5$ & 3 & $0-4$ & 0.052 & 0.979 \\
\hline & $4 \mathrm{~h}$ & 4.5 & $0-5$ & 3 & $2-4$ & 0.226 & 0.543 \\
\hline & $12 \mathrm{~h}$ & 4 & $3-4$ & 4 & $3-4$ & 0.445 & 0.308 \\
\hline & $24 \mathrm{~h}$ & 3 & $2-4$ & 4 & $2-4$ & 0.809 & 0.102 \\
\hline & $48 \mathrm{~h}$ & 3 & $0-3$ & 2 & $1-3$ & 0.308 & 0.423 \\
\hline & $72 \mathrm{~h}$ & 0 & $0-0$ & 0 & $0-0$ & 1 & 0 \\
\hline & 7 Days & 0 & $0-0$ & 0 & $0-0$ & 1 & 0 \\
\hline \multirow[t]{8}{*}{ Multiple visits } & Pre-operative & 5 & $3-7$ & 6 & $5-7$ & 0.211 & 0.562 \\
\hline & Immediate post-operative & 3.5 & $0-6$ & 4 & $3-6$ & 0.471 & 0.308 \\
\hline & $4 \mathrm{~h}$ & 4 & $0-6$ & 4 & $3-4$ & 0.268 & 0.487 \\
\hline & $12 \mathrm{~h}$ & 3.5 & $0-5$ & 3 & $2-3$ & 0.180 & 0.6 \\
\hline & $24 \mathrm{~h}$ & 2 & $0-4$ & 1 & $0-2$ & 0.622 & 0.204 \\
\hline & $48 \mathrm{~h}$ & 0.5 & $0-3$ & 0 & $0-1$ & 0.625 & 0.204 \\
\hline & $72 \mathrm{~h}$ & 0 & $0-2$ & 0 & $0-0$ & 0.067 & 0.524 \\
\hline & 7 Days & 0 & $0-0$ & 0 & $0-0$ & 1 & 0 \\
\hline
\end{tabular}


Table 4: Comparison between pain VAS scores at different times within each group

\begin{tabular}{|c|c|c|c|c|c|c|c|c|}
\hline \multirow[t]{2}{*}{ Time } & \multicolumn{2}{|c|}{ Single visit-AH Plus $(n=10)$} & \multicolumn{2}{|c|}{ Single visit-Total Fill $(n=10)$} & \multicolumn{2}{|c|}{ Multiple visits-AH Plus $(n=10)$} & \multicolumn{2}{|c|}{ Multiple visits-Total Fill $(n=10)$} \\
\hline & Median & Range & Median & Range & Median & Range & Median & Range \\
\hline Pre-operative & $6^{A}$ & $5-7$ & $5^{A}$ & $4-6$ & $5^{A}$ & $3-7$ & $6^{A}$ & $5-7$ \\
\hline Immediate post-operative & $5^{\mathrm{AB}}$ & $0-5$ & $3^{B}$ & $0-4$ & $3.5^{\mathrm{B}}$ & $0-6$ & $4^{\mathrm{B}}$ & $3-6$ \\
\hline $4 \mathrm{~h}$ & $4.5^{\mathrm{B}}$ & $0-5$ & $3^{B}$ & $2-4$ & $4^{A B}$ & $0-6$ & $4^{\mathrm{B}}$ & $3-4$ \\
\hline $12 \mathrm{~h}$ & $4^{\mathrm{BC}}$ & $3-4$ & $4^{\mathrm{B}}$ & $3-4$ & $3.5^{\mathrm{B}}$ & $0-5$ & $3^{\mathrm{B}}$ & $2-3$ \\
\hline $24 \mathrm{~h}$ & $3^{c}$ & $2-4$ & $4^{\mathrm{B}}$ & $2-4$ & $2^{\mathrm{c}}$ & $0-4$ & $1^{\mathrm{C}}$ & $0-2$ \\
\hline $48 \mathrm{~h}$ & $3^{c}$ & $0-3$ & $2^{\mathrm{c}}$ & $1-3$ & $0.5^{\mathrm{D}}$ & $0-3$ & $0^{\mathrm{C}}$ & $0-1$ \\
\hline $72 \mathrm{~h}$ & $0^{D}$ & $0-0$ & $0^{\mathrm{D}}$ & $0-0$ & $0^{\mathrm{D}}$ & $0-2$ & $0^{\mathrm{C}}$ & $0-0$ \\
\hline 7 Days & $0^{D}$ & $0-0$ & $0^{D}$ & $0-0$ & $0^{\mathrm{D}}$ & $0-0$ & $0^{\mathrm{C}}$ & $0-0$ \\
\hline $\mathrm{p}$-value & $<0.001^{*}$ & & $<0.001^{*}$ & & $<0.001^{*}$ & & $<0.001^{*}$ & \\
\hline Effect size (w) & 0.805 & & 0.749 & & 0.796 & & 0.83 & \\
\hline
\end{tabular}

was used for comparisons between the groups. The significance level was set at $p \leq 0.05$. Statistical analysis was performed with IBM SPSS Statistics for Windows, Version 23.0. Armonk, NY: IBM Corp.

\section{Results}

\section{Pain assessment using VAS (Tables 2-4)}

Comparison between single and multiple visits

Whether with $\mathrm{AH}$ Plus or Total Fill sealers, there was no statistically significant difference between pain scores of patients who had single or multiple visits pre-operatively, immediately post-operative, after 4, 12, 24, 48, $72 \mathrm{~h}$ as well as after 7 days (Table 2).

\section{Comparison between sealer types}

Whether after single or multiple visits, there was no statistically significant difference between pain scores of AH Plus and Total Fill sealers pre-operatively, immediately post-operative, after $4,12,24,48,72 \mathrm{~h}$ as well as after 7 days (Table 3 ).

\section{Changes by time within each group}

As regards single visit with AH Plus sealer group, there was a statistically significant change in median pain scores by time $(p<0.001$, Effect size $=0.805)$. Pair-wise comparisons between time periods revealed that there was no statistically significant change in median pain scores immediately post-operative as well as from immediate post-operative to $4 \mathrm{~h}$. However, the median pain score after $4 \mathrm{~h}$ showed statistically significant lower median score than pre-operative measurement. From 4 to 12 as well as $12-24 \mathrm{~h}$; there was no statistically significant change in median pain score. However, the median pain score after $24 \mathrm{~h}$ showed statistically significantly lower median value than pre-operative, immediate post-operative and $4 \mathrm{~h}$ scores. There was also no statistically significant change in median pain scores from 24 to $48 \mathrm{~h}$ followed by a statistically significant decrease in median pain score from 48 to $72 \mathrm{~h}$. There was no statistically significant change in median pain scores from $72 \mathrm{~h}$ to 7 days.

In single visit with Total Fill sealer group, there was a statistically significant change in median pain scores by time $(p<0.001$, Effect size $=0.749$ ). Pairwise comparisons between time periods revealed that there was a statistically significant decrease in median pain scores immediately post-operative followed by non-statistically significant change from immediate post-operative to $4 \mathrm{~h}, 4-12$ as well as $12-24 \mathrm{~h}$. From 24 to 48 as well as $48-72 \mathrm{~h}$, there was a statistically significant decrease in median pain score. There was no statistically significant change in median pain scores from $72 \mathrm{~h}$ to 7 days.

As regards multiple visits with $\mathrm{AH}$ Plus sealer group; there was a statistically significant change in median pain scores by time $(p<0.001$, Effect size $=$ 0.796). Pair-wise comparisons between time periods revealed that there was a statistically significant decrease in median pain scores immediately postoperative followed by non-statistically significant change from immediate post-operative to $4 \mathrm{~h}$ as well as from 4 to $12 \mathrm{~h}$. From 12 to 24 as well as $24-48 \mathrm{~h}$, there was a statistically significant decrease in median pain score. There was no statistically significant change in median pain scores from 48 to $72 \mathrm{~h}$ as well as from $72 \mathrm{~h}$ to 7 days.

Table 5: Comparison between lamina dura thickness $(\mathrm{mm})$ after single or multiple visits

\begin{tabular}{|c|c|c|c|c|c|c|c|}
\hline \multirow[t]{2}{*}{ Sealer } & \multirow[t]{2}{*}{ Time } & \multicolumn{2}{|c|}{ Single visit $(n=10)$} & \multicolumn{2}{|c|}{ Multiple visits $(n=10)$} & \multirow[t]{2}{*}{$p$-value } & \multirow[t]{2}{*}{ Effect size (Partial Eta Squared) } \\
\hline & & Mean & SD & Mean & SD & & \\
\hline \multirow[t]{5}{*}{ AH Plus } & Pre-operative & 0.269 & 0.061 & 0.289 & 0.067 & 0.425 & 0.018 \\
\hline & 1 month & 0.244 & 0.064 & 0.253 & 0.06 & 0.721 & 0.004 \\
\hline & 3 months & 0.223 & 0.05 & 0.233 & 0.052 & 0.630 & 0.007 \\
\hline & 6 months & 0.204 & 0.034 & 0.204 & 0.048 & 0.995 & 0.000001 \\
\hline & 9 months & 0.194 & 0.025 & 0.174 & 0.036 & 0.133 & 0.062 \\
\hline \multirow[t]{5}{*}{ Total Fill } & Pre-operative & 0.28 & 0.034 & 0.278 & 0.051 & 0.929 & 0.0002 \\
\hline & 1 month & 0.269 & 0.033 & 0.255 & 0.052 & 0.559 & 0.010 \\
\hline & 3 months & 0.241 & 0.035 & 0.241 & 0.041 & 0.988 & 0.00001 \\
\hline & 6 months & 0.206 & 0.023 & 0.201 & 0.034 & 0.770 & 0.002 \\
\hline & 9 months & 0.173 & 0.028 & 0.176 & 0.024 & 0.828 & 0.001 \\
\hline
\end{tabular}


In multiple visits with Total Fill sealer group, there was a statistically significant change in median pain scores by time $(p<0.001$, Effect size $=0.83)$. Pairwise comparisons between time periods revealed that there was a statistically significant decrease in median pain scores immediately post-operative followed by non-statistically significant change from immediate post-operative to $4 \mathrm{~h}$ as well as $4-12 \mathrm{~h}$. From 12 to $24 \mathrm{~h}$, there was a statistically significant decrease in median pain score. There was no statistically significant change in median pain scores from 24 to $48,48-72$ as well as from $72 \mathrm{~h}$ to 7 days (Table 4 ).

\section{Lamina dura thickness ( $\mathrm{mm}$ ) (Tables 5-7)}

Comparison between single and multiple visits

Whether with AH Plus or Total Fill sealers, there was no statistically significant difference between lamina dura thickness of patients who had single or multiple visits pre-operatively, after 1 month, 3,6 as well as after 9 months (Table 5).

\section{Comparison between sealer types}

Whether after single or multiple visits, there was no statistically significant difference between lamina dura thickness after using AH Plus or Total Fill sealers pre-operatively, after 1 month, 3, 6 as well as after 9 months (Table 6).

\section{Changes by time within each group}

As regards single visit with $\mathrm{AH}$ Plus sealer group, there was a statistically significant change in mean lamina dura thickness by time $(p<0.001$, Effect size $=0.495$ ). Pair-wise comparisons between time periods revealed that there was a statistically significant decrease in mean Lamina Dura thickness after 1 month, from 1 to 3 months as well as from 3 to 6 months. From 6-9 months; there was no statistically significant change in mean lamina dura thickness.

In single visit with Total Fill sealer group, there was a statistically significant change in mean Lamina Dura thickness by time $(p<0.001$, Effect size $=0.708)$. Pair-wise comparisons between time periods revealed that there was no statistically significant change in mean lamina dura thickness after 1 month followed by a statistically significant decrease in mean lamina dura thickness from 1 to 3, 3-6 as well as from 6 to 9 months.

As regards multiple visits with $\mathrm{AH}$ Plus sealer group, there was a statistically significant change in mean Lamina Dura thickness by time $(p<0.001$, Effect size $=0.725$ ). Pair-wise comparisons between time periods revealed that there was a statistically significant decrease in mean lamina Dura thickness after 1 month, from 1 to $3,3-6$ as well as from 6 to 9 months (Table 7).

Similarly, in multiple visits with Total Fill sealer group, there was a statistically significant change in mean Lamina Dura thickness by time $(p<0.001$, Effect size $=0.682$ ). Pair-wise comparisons between time periods revealed that there was a statistically significant decrease in mean lamina dura thickness after 1 month, from 1 to $3,3-6$ as well as from 6 to 9 months.

\section{Discussion}

The present pilot clinical study compared the effect of visit protocol (single and multiple) and different endodontic sealers (resin sealer and bioceramic sealer) on pain and radiographic alterations were carried out. A pain scale and parallel technique for peri-apical radiographic view were used. Single visit versus multiple visits has long been an issue of debate in root canal treatment (RCT) research [26].

In this current study, two types of endodontic sealers were used, representing 2 different categories (resin and bioceramic). Over years AH Plus endodontic sealer, which is a resin sealer, has become the gold standard against which newly introduced sealers are assessed, especially if they are based on new concepts. This good reputation of $\mathrm{AH}$ Plus was well earned by thousands of long-term successful cases all over the world and hundreds of researches that showed its efficient physical [21], [27], [28].

Epoxy resin-based sealers, such as AH Plus sealer can bond to dentin. Furthermore, it possesses an antimicrobial activity against Enterococcus faecalis, biocompatibility, long-term dimensional stability and acceptable flow [21].

Table 6: Comparison between lamina dura thickness after using the two sealers

\begin{tabular}{|c|c|c|c|c|c|c|c|}
\hline \multirow[t]{2}{*}{ Visit } & \multirow[t]{2}{*}{ Time } & \multicolumn{2}{|c|}{ AH Plus $(n=10)$} & \multicolumn{2}{|c|}{ Total Fill $(n=10)$} & \multirow[t]{2}{*}{$p$-value } & \multirow[t]{2}{*}{ Effect size (Partial Eta Squared) } \\
\hline & & Mean & SD & Mean & SD & & \\
\hline \multirow[t]{5}{*}{ Single visit } & Pre-operative & 0.269 & 0.061 & 0.28 & 0.034 & 0.636 & 0.006 \\
\hline & 1 month & 0.244 & 0.064 & 0.269 & 0.033 & 0.308 & 0.029 \\
\hline & 3 months & 0.223 & 0.05 & 0.241 & 0.035 & 0.386 & 0.021 \\
\hline & 6 months & 0.204 & 0.034 & 0.206 & 0.023 & 0.916 & 0.0003 \\
\hline & 9 months & 0.194 & 0.025 & 0.173 & 0.028 & 0.115 & 0.068 \\
\hline \multirow[t]{5}{*}{ Multiple visits } & Pre-operative & 0.289 & 0.067 & 0.278 & 0.051 & 0.677 & 0.005 \\
\hline & 1 month & 0.253 & 0.06 & 0.255 & 0.052 & 0.934 & 0.0002 \\
\hline & 3 months & 0.233 & 0.052 & 0.241 & 0.041 & 0.687 & 0.005 \\
\hline & 6 months & 0.204 & 0.048 & 0.201 & 0.034 & 0.857 & 0.001 \\
\hline & 9 months & 0.174 & 0.036 & 0.176 & 0.024 & 0.889 & 0.001 \\
\hline
\end{tabular}


Bioceramics were introduced in endodontics as root repair cements and root canal sealers. Total fill Bioceramic sealer was chosen to be the other arm of comparison in this study, because of its promising results in different researches and its intriguing concept, being insoluble and hydrophilic depending on the dentin inherit moisture for its setting reaction, also it possesses antimicrobial properties, biocompatibility, radiopacity, and chemical and dimension stability [22], [20], [29].

It is well known that pain perception is a highly subjective and variable experience modulated by multiple physical and psychological factors. Pain reporting is influenced by many factors other than experimental procedures. In addition, the measurements of pain are fraught with hazards and opportunities for error. In this study, VAS has been used. Pain has also been visually and verbally quantified to a better understanding by patients. Pain scales are based on the theory that pain intensity is continuous without jumps or intervals. The VAS is suitable for research use and has been extensively utilized within medicine and dentistry. It simplifies pain rating by allowing patients to quantify the extent of their pain by rating it from 0 to 10 [30], [31].

The use of periapical radiographs to assess the success in endodontic treatment is a routine practice. One of the disadvantages of this method is the reproducibility of the assessment results [32]. Reviewers were experienced clinicians, who received training on radiographic assessment on 50 radiographs. They draw the attention that there is no doubt that cone beam computed tomography (CBCT) produces better imaging to improve the validity of the assessment of periapical bone healing after endodontic treatment [33]. $\mathrm{CBCT}$ requires larger doses of irradiation, so it should not be the standard assessment method for scientific research [26], [32].

As regard post-operative pain no statistical significant difference was found between single and multiple visits. This is in accordance with Manfredi et al. [34] and Ezpeleta et al. [35]. This may be due to that it is difficult to determine if a single or multiple factors elicit pain. If a root canal system was not cleaned properly, residual infection may cause exacerbation by imbalances in the host-bacteria relationship, or the presence of decisively pathogenic bacteria before the initiation of treatment [36]. For this reason, only vital cases were included, while persisting infection cases were excluded as a cause of post-operative pain. A mechanical reason as over instrumentation; chemical factors include the extrusion of medications, filling materials, or irrigants may result in post-operative pain [37]. Furthermore, the results are based on patient's reports and the pain is subjective nature, so the evaluation of patients may show wide variations as there are multiple factors that could influence the individual reaction to pain [38].

Moreover, the instrumentation technique can influence discomfort or pain during endodontic therapy. Crown down technique was utilized which may effectively minimize post-operative pain, this is in agreement with Goreva and Petrikas [33]. Revo S rotary files, used in this study, acts in a sneaky such as motion which results in less debris extrusion, that decreasing post-operative pain. Only single-rooted teeth with a single canal were included to facilitate WL control and to avoid over instrumentation [11].

The results of this current study contradict with that of Albashaireh and Alnegrish [38] who reported that post-operative pain was lower in single visit. This may be due to that the root canal is obturated directly after instrumentation and irrigation aiming to seal remaining bacteria and deprived them from both space and nutrition [15], [39]. At the other side, Jabeen and Khursiduzzaman [40] concluded that post-operative pain was less in multiple visits compared to that of single visit. This may be due to that the application of antibacterial medication as $\mathrm{CA}(\mathrm{OH})_{2}$ which is injected to disinfect canals between treatment visits [41]. Furthermore, this finding is in accordance with Figini et al. [15] and Ghoddusi et al. [42] who reported that pain increased after single visit treatment due to longer working time which simulate inflammatory response and that single visit treatment significantly increase the risk of flaring and swelling.

All these contradictions may be due to the fact that these researches were carried out on non-vital teeth, also the difference in the follow-up period. Multiplevisit treatment is recommended when complications is suspected (teeth with periapical lesions) [43].

The results showed that whether with $\mathrm{AH}$ Plus or Total Fill sealers, and there was no statistically significant difference between pain scores among tested patients. This is in accordance with the results concluded by Graunaite et al. [44] They concluded

Table 7: Comparison between lamina dura thickness $(\mathrm{mm})$ at different times within each group

\begin{tabular}{|c|c|c|c|c|c|c|c|c|}
\hline \multirow[t]{2}{*}{ Time } & \multicolumn{2}{|c|}{ Single visit-AH Plus $(n=10)$} & \multicolumn{2}{|c|}{ Single visit-Total Fill $(n=10)$} & \multicolumn{2}{|c|}{$\begin{array}{l}\text { Multiple visits-AH } \\
\text { Plus }(n=10)\end{array}$} & \multicolumn{2}{|c|}{$\begin{array}{l}\text { Multiple visits-Total } \\
\text { Fill }(n=10)\end{array}$} \\
\hline & Mean & SD & Mean & SD & Mean & SD & Mean & SD \\
\hline Pre-operative & $0.269^{A}$ & 0.061 & $0.28^{A}$ & 0.034 & $0.289^{A}$ & 0.067 & $0.278^{A}$ & 0.051 \\
\hline 1 month & $0.244^{\mathrm{B}}$ & 0.064 & $0.269^{A}$ & 0.033 & $0.253^{\mathrm{B}}$ & 0.06 & $0.255^{\mathrm{B}}$ & 0.052 \\
\hline 3 months & $0.223^{\mathrm{c}}$ & 0.05 & $0.241^{\mathrm{B}}$ & 0.035 & $0.233^{\mathrm{c}}$ & 0.052 & $0.241^{\mathrm{C}}$ & 0.041 \\
\hline 6 months & $0.204^{\mathrm{D}}$ & 0.034 & $0.206^{\mathrm{C}}$ & 0.023 & $0.204^{\mathrm{D}}$ & 0.048 & $0.201^{\mathrm{D}}$ & 0.034 \\
\hline 9 months & $0.194^{\mathrm{D}}$ & 0.025 & $0.173^{\mathrm{D}}$ & 0.028 & $0.174^{E}$ & 0.036 & $0.176^{\mathrm{E}}$ & 0.024 \\
\hline $\mathrm{p}$-value & $<0.001^{*}$ & & $<0.001^{*}$ & & $<0.001^{*}$ & & $<0.001^{*}$ & \\
\hline Effect size (Partial Eta Squared) & 0.495 & & 0.708 & & 0.725 & & 0.682 & \\
\hline
\end{tabular}


that $\mathrm{AH}$ Plus and Total Fill perform the same as regard intensity and occurrence of post-operative pain in teeth. At the same time in vitro studies reported that the differences in cytotoxicity between $\mathrm{AH}$ Plus and Total Fill, does not seem to reflect clinically. For AH Plus mild pain is probably related to the self-limiting leaching of cytotoxic components as the material sets. This irritation to the host peaks at 3-7 days [17], [22], [45], [46]. As for Total Fill, the persistence of post obturation pain may extend for days, which can be explained by the maintenance of irritating components and therefore inflammatory mediators [47], [48].

The highest VAS score was reported at $24 \mathrm{~h}$ after obturation and decreased with time. One could speculate that cytotoxic unpolymerized root canal sealers known to induce reactive oxygen species (ROS) formation before material setting and their leaching components could have played a role during the first $24 \mathrm{~h}$ [27], [35].

On the other hand, Paz et al. [49] inversely reported that highest post-operative pain using single cone + bioceramic and continuous wave + resin sealer revealed the least levels of pain. Although, it was not the purpose of our study, comparing the obturation techniques. The lamina dura thickness results revealed a non-significant difference between both sealers used as well as duration of treatment. This result is in accordance with of Wong et al. [50]. They draw the attention that there was no clinical sign and symptom and no radiographic radiolucency observed by the clinicians in the follow-up examination.

The null hypothesis was accepted as the results showed no significant difference as regard pain and lamina dura thickness for both techniques for RCT (single versus multiple visits), as well as for types of sealers used.

\section{Conclusions}

Post-operative pain and lamina dura thickness were not affected by neither with the number of visits nor with type of sealer.

\section{References}

1. Sathorn C,ParashosP,MesserH. The prevalence of postoperative pain and flare-up in single- and multiple-visit endodontic treatment: A systematic review. Int Endod J. 2008;41(2):91-9. https://doi.org/10.1111/j.1365-2591.2007.01316.x PMid:17956561

2. Genet JM, Hart AA, Wesselink PR, van Velzen SK. Preoperative and operative factors associated with pain after the first endodontic visit. Int Endod J. 1987;20(2):53-64. https://doi. org/10.1111/j.1365-2591.1987.tb00590.x

PMid:3471726

3. Patil AA, Joshi SB, Bhagwat SV, Patil SA. Incidence of postoperative pain after single visit and two visit rootcanal therapy: A randomized controlled trial. J Clin Diagn Res. 2016;10(5):9-12. https://doi.org/10.7860/JCDR/2016/16465.7724

PMid:27437339

4. Kherlakian D, Cunha RS, Ehrhardt IC, Zuolo ML, Kishen A, da Silveira Bueno CE. Comparison of the incidence of postoperative pain after using 2 reciprocating systems and a continuous rotary system: A prospective randomized clinical trial. J Endod 2016;42(2):171-6. https://doi.org/10.1016/j. joen.2015.10.011

PMid:26614017

5. Thakur S, Emil J, Paulaian B. Evaluation of mineral trioxide aggregate as root canal sealer: A clinical study. J Conserv Dent. 2013;16(6):494-8. https://doi.org/10.4103/0972-0707.120944

PMid:24347880

6. Pasqualini $D$, Corbella $S$, Alovisi M. Postoperative quality of life following single-visit root canal treatment performed by rotary or reciprocating instrumentation: A randomized clinical trial. Int Endod J. 2016;49(11):1030-9. https://doi.org/10.1111/iej.12563 PMid:26468626

7. Comparin D, Moreira EJ, Souza EM, De-Deus G, Arias A, Silva EJ . Postoperative pain after endodontic retreatment using rotary or reciprocating instruments: A randomized clinical trial. J Endod. 2017;43(7):1084-8. https://doi.org/10.1016/j.joen.2017.02.010 PMid:28477995

8. Shahi S, Asghari V, Rahimi S, Lotfi M, Samiei M, Yavari H, et al. Postoperative pain after endodontic treatment of asymptomatic teeth using rotary instruments: A randomized clinical trial. Iran Endod J. 2016;11(1):38-43. https://doi.org/10.7508/ iej.2016.01.008

PMid:26843876

9. de Oliveira Brandao-Neto D, Mello JV, Marceliano-Alves MF, Carvalho Coutinho TM, Marceliano EF, Galhardi MP, et al. Final endodontic irrigation with $2 \%$ peracetic acid: Antimicrobial activity and cytotoxicity. Eur J Dent. 2021;15(3):533-8. https:// doi.org/10.1055/s-0041-1723068

PMid:33535247

10. Martins CM, Batista VE, Souza AC, Andrada AC, Mori GG, Gomes Filho JE. Reciprocating kinematics leads to lower incidences of postoperative pain than rotary kinematics after endodontic treatment: A systematic review and meta-analysis of randomized controlled trial. J Conserv Dent. 2019;22(4):320-31. https://doi.org/10.4103/JCD.JCD_439_18

PMid:31802813

11. Arslan H, Guven $Y$, Karatas E, Doganay E. Effect of the simultaneous working length control during root canal preparation on postoperative pain. J Endod. 2017;43(9):1422-7. https://doi.org/10.1016/j.joen.2017.04.028 PMid:28735785

12. Tan HS, Lim KC, Lui JN, Lai WM, Yu VS. Postobturation pain associated with tricalcium silicate and resin based sealer techniques: A randomized clinical trial. J Endod. 2021;47(2):169-77. https://doi.org/10.1016/j.joen.2020.10.013 PMid:33098889

13. Fonseca B, Coelho MS, Bueno CE, Fontana CE, Martin AS, Rocha DG. Assessment of extrusion and postoperative pain of a bioceramic and resin-based root canal sealer. Eur J Dent. 2019;13(3):343-8. https://doi.org/10.1055/s-0039-3399457 PMid:31794999

14. Malhotra N, Kundabala M, Acharya S. Contemporary endodontic approach: Single-visit root canal treatment revisited. Endod 
Pract Today. 2009;3(3):215-25.

15. Figini L, Lodi G, Gorni F, Gagliani M. Single versus multiple visits for endodontic treatment of permanent teeth: A cochrane systematic review. J Endod. 2008;34(9):1041-7. https://doi. org/10.1016/j.joen.2008.06.009

PMid:18718362

16. Prado MC, de Carvalho NK, Vitti RP, Ogliari FA, Sassone LM, Silva EJ. Bond strength of experimental root canal sealers based on MTA and butyl ethylene glycol disalicylate. Braz Dent J. 2018;29(2):195-201. https://doi. org/10.1590/0103-6440201801833 PMid:29898068

17. Zhang $W$, Peng B. Tissue reactions after subcutaneous and intraosseous implantation of iRoot SP, MTA and AH Plus. Dent Mater J 2015;34(6):774-80. https://doi.org/10.4012/ dmj.2014-271

\section{PMid:26632225}

18. Candeiro GT, Correia FC, Duarte MA, Ribeiro-Siqueira DC Gavini G. Evaluation of radiopacity, $\mathrm{pH}$, release of calcium ions, and flow of a bioceramic root canal sealer. J Endod. 2012;38(6):842-5. https://doi.org/10.1016/j.joen.2012.02.029 PMid:22595123

19. Silva EC, Tanomaru-Filho M, da Silva GF, Delfino MM, Cerri PS, Guerreiro-Tanomaru JM, et al. Biocompatibility and bioactive potential of new calcium silicate-based endodontic sealers: Bio-C Sealer and Sealer Plus BC. J Endod. 2020;46(10):1470-7. https://doi.org/10.1016/j.joen.2020.07.011 PMid:32682789

20. Zordan-Bronzel CL, Esteves Torres FF, Tanomaru-Filho M, Chávez-Andrade GM, Bosso-Martelo R, Guerreiro-Tanomaru JM. Evaluation of physicochemical properties of a new calcium silicatebased sealer, Bio-C Sealer. J Endod. 2019;45(10):1248-52. https://doi.org/10.1016/j.joen.2019.07.006 PMid:31447172

21. Guven EP, Tasli PN, Yalvac ME, Sofiev N, Kayahan MB, Sahin F. In vitro comparison of induction capacity and biomineralization ability of mineral trioxide aggregate and a bioceramic root canal sealer. Int Endod J. 2013;46(12):1173-82. https://doi. org/10.1111/iej. 12115

PMid:23617276

22. Zhang W, Li Z, Peng B. Ex vivo cytotoxicity of a new calcium silicate-basedcanal fillingmaterial. IntEndodJ.2010;43(9):769-74. https://doi.org/10.1111/j.1365-2591.2010.01733.x PMid:20546044

23. Ozkocak I, Sonat B. Evaluation of effects on the adhesion of various root canal sealers after Er: YAG laser and irrigants are used on the dentin surface. J Endod. 2015;41(8):1331-6. https:// doi.org/10.1016/j.joen.2015.03.004 PMid:25892511

24. Mohan SM, Kaushik SK. Root canal treatment using thermoplasticized carrier condensation technique. Med J Armed Forces India. 2009;65(4):336-41. https://doi.org/10.1016/ S0377-1237(09)80095-6

PMid:27408288

25. Chu $\mathrm{CH}$, Lo EC, Cheung GS. Outcome of root canal treatment using Thermafil and cold lateral condensation filling techniques. Int Endod J. 2005;38(3):179-85. https://doi. org/10.1111/j.1365-2591.2004.00929.x

PMid: 15743421

26. Wong AW, Tsang CS, Zhang S, Li K, Zhang C, Chu C. Treatment outcomes of single-visit versus multiple-visit non-surgical endodontic therapy: A randomised clinical trial. BMC Oral Health. 2015;15:162. https://doi.org/10.1186/s12903-015-0148-x PMid:26687126
27. Sharma S, Blicher B, Pryles R, Lin J. Single-Vs multiple-visit root canal therapy. Treatment selection requires consideration of factors beyond prognosis. Inside Dent. 2019;15(6).

28. Swetah CS, Ranjan M. Single visit vs. multiple visits for endodontic treatment: A review. Int J Sci Dev Res. 2017;2(10):23-7.

29. Lopez-García S, Pecci-Lloret MR, Guerrero-Girones J, Pecci-Lloret MP, Lozano A, Llena C, et al. Comparative cytocompatibility and mineralization potential of Bio-C sealer and totalfill BC sealer. Materials (Basel). 2019;12:3087. https:// doi.org/10.3390/ma12193087

PMid:31546696

30. Giacomino CM, Wealleans JA, Kuhn N, Diogenes A. Comparative biocompatibility and osteogenic potential of two bioceramic sealers. J Endod. 2019;45(1):51-6. https://doi. org/10.1016/j.joen.2018.08.007 PMid:30558798

31. Seymour RA, Simpson JM, Charlton EJ, Phillips ME. AN Evaluation of length and end-phrase of visual analogue scales in dental pain. Pain. 1985;21(2):1177-85. https://doi. org/10.1016/0304-3959(85)90287-8

PMid:3982841

32. Venskutonis T, Plotino G, Tocci L, Gambarini G, Maminskas J, Juodzbalys $G$. Periapical and endodontic status scale based on periapical bone lesions and endodontic treatment quality evaluation using cone-beam computed tomography. J Endod. 2015;41(2):190-6. https://doi.org/10.1016/j.joen.2014.10.017 PMid:25498834

33. Goreva LA, Petrikas AZ. Postobturation pain associated with endodontic treatment. Stomatologiia (Mosk). 2004;83(2):14-6. PMid: 15111950

34. Manfredi M, Figini L, Gagliani M, Lodi G. Single versus multiple visits for endodontic treatment of permanent teeth. Cochrane Database Syst. Rev. 2016;12(12):CD005296.

PMid:27905673

35. Ezpeleta LOA, Garcia CG, Cosano LC, González JM, Frías FJ, Egea JJ. Postoperative pain after one-visit root-canal treatment on teeth with vital pulps: Comparison of three different obturation techniques. Med Oral Patol Oral Cir Bucal. 2012;17(4):e721-7. https://doi.org/10.4317/medoral.17898 PMid:22322522

36. Clark DS, EIDeeb ME. Apical sealing ability of metal versus plastic carrier Thermafil obturators. J Endod. 1993;19(1):4-9. PMid:8289026

37. Gondim E Jr., Setzer FC, Dos Carmo CB, Kim S. Postoperative pain after the application of two different irrigation devices in a prospective randomized clinical trial. J Endod. 2010;36(8):1295-301.

38. Albashaireh ZS, Alnegrish AS. Postobturation pain after single- and multiple-visit endodontic therapy: A prospective study. J Dent. 1998;26(3):227-32. https://doi.org/10.1016/ s0300-5712(97)00006-7 PMid:9594474

39. Weiger R, Rosendahl R, Lost C. Influence of calcium hydroxide intracanal dressings on the prognosis of teeth with endodontically induced periapical lesions. Int Endod J 2000;33(3):219-26. https://doi.org/10.1046/j.1365-2591.1999.00298.x PMid: 11307438

40. Jabeen S, Khurshiduzzaman M. Incidence of post obturation pain following single and multi visit root canal treatment in a teaching hospital of Bangladesh. Mymensingh Med J. 2014;23(2):254-60. PMid:24858151

41. Han GY, Park SH, Yoon TC. Antimicrobial activity of $\mathrm{Ca}(\mathrm{OH}) 2$ containing pastes with Enterococcus faecalis 
in vitro. J Endod. 2001;27(5):328-32. https://doi. org/10.1097/00004770-200105000-00004

PMid: 11485250

42. Ghoddusi J, Javidi M, Zarrabi M, Bagheri H. Flare ups incidence and severity after using calcium hydroxide as an intracanal dressing. N Y State Dent J. 2006;72(4):24-8.

PMid:16925009

43. Schwendicke F, Gostemeyer G. Single-visit or multiple-visit root canal treatment: Systematic review, meta analysis and trial sequential analysis. BMJ Open. 2017;7(2):e013115. https://doi. org/10.1136/bmjopen-2016-013115

PMid:28148534

44. Graunaite I, Skucaite N, Lodiene G, Agentiene I, Machiulskiene V. Effect of resin-based and bioceramic root canal sealers on postoperative pain: A split-mouth randomized controlled trial. J Endod. 2018;44(5):689-693. https://doi.org/10.1016/j. joen.2018.02.010 PMid:29571915

45. Ali A, Olivieri JG, Duran-Sindreu F, Abella F, Roig M, García-Font $\mathrm{M}$, et al. Influence of preoperative pain intensity on postoperative pain after root canal treatment: A prospective clinical study. J Dent. 2016;45:39-42.

46. Ates AA, Dumani A, Yoldas O, Unal I. Post-obturation pain following the use of carrier-based system with $\mathrm{AH}$ Plus or iRoot SP sealers: A randomized controlled clinical trial. Clin Oral Investig. 2019;23(7):3053-61. https://doi.org/10.1007/ s00784-018-2721-6

PMid:30397735

47. Shashirekha G, Jena A, Pattanaik S, Rath J. Assessment of pain and dissolution of apically extruded sealers and their effect on the periradicular tissues. J Conserv Dent. 2018;21:546-50. https://doi.org/10.4103/JCD.JCD_224_18

PMid:30294119

48. de-Figueiredo FE, Lima LF, Lima GS, Lima GS, Oliveira LS, Ribeiro MA, et al. Apical periodontitis healing and postoperative pain following endodontic treatment with a reciprocating singlefile, single-cone approach: A randomized controlled pragmatic clinical trial. PLoS One 2020;15:e0227347. https://doi. org/10.1371/journal.pone.0227347 PMid:32012166

49. Paz A, Vasconcelos I, Ginjeira A. Evaluation of postoperative pain after using bioceramic materials as endodontic sealers. EC Dent Sci. 2018;17(10):1739-48.

50. Wong AW, Zhang S, Zhang $\mathrm{CF}$, Chu $\mathrm{CH}$. Perceptions of single-visit and multiple-visit endodontic treatment: A survey of endodontic specialists and general dentists in Hong Kong. J Investig Clin Dent. 2015;38:1-9. 